Boletín de la Sociedad Geológica Mexicana

VOLUMEN 65, NÚM. 1, 2013, P. 189-200

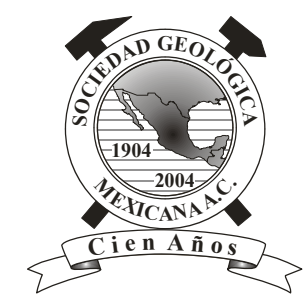

\title{
Ammonoids from the Maastrichtian (Late Cretaceous) at El Zancudo, Nuevo Laredo, Tamaulipas, Mexico
}

\author{
Christina Ifrim ${ }^{1, *}$, Wolfgang Stinnesbeck ${ }^{1}$ \\ ${ }^{1}$ Geowissenschaftliches Institut, Universität Heidelberg, Im Neuenheimer Feld 234, 69120 Heidelberg, Germany. \\ *christina.ifrim@geow.uni-heidelberg.de
}

\begin{abstract}
A small assemblage of Maastrichtian ammonoids was collected at El Zancudo, south of Nuevo Laredo, Mexico, on the border with Texas. They are preserved as goethitic internal moulds of the innermost whorls. Nine taxa are described in abbreviated form. Eight taxa have been recorded from northeastern Mexico before: Baculites ovatus, Brahmaites (Anabrahmaites) vishnu (Forbes, 1846), Diplomoceras cylindraceum, Fresvillia sp. indet., Gaudryceras kayei, Hypophylloceras (Neophylloceras) cf. H. (N.) surya, Phyllopachyceras forbesianum, and Tetragonites superstes. The genus Discoscaphites was recorded and described for the first time in this region. The assemblage indicates an early late Maastrichtian age and is compared to other ammonoid assemblages from Texas and northeastern Mexico. It provides an important level marker for long-distance correlation into the deltaic sediments of northeastern Mexico, known as the Difunta Group.
\end{abstract}

Keywords: ammonoids, biostratigraphy, Cretaceous, Maastrichtian, Mexico, paleobiogeography, systematic description.

\section{Resumen}

Se describe una pequeña asociación de amonites del Maastrichtiano hallada en la localidad de El Zancudo, al sur de Nuevo Laredo y cerca de la frontera con Texas. Sólo fueron preservadas las vueltas internas de los fósiles como moldes interiores de goethita. Se describen nueve especies de manera breve. Ocho de ellos ya han sido registrados para el noreste de México: Baculites ovatus, Brahmaites (Anabrahmaites) vishnu, Diplomoceras cylindraceum, Fresvillia sp. indet., Gaudryceras kayei, Hypophylloceras (Neophylloceras) cf. H. (N.) surya, Phyllopachyceras forbesianum, y Tetragonites superstes. El género Discoscaphites se registra y se describe por primera vez para esta región. Esta asociación indica una edad que corresponde a la parte temprana del Maastrichtiano tardio y se compara con otras asociaciones coetáneas de amonites de Texas y de México. El horizonte fosilífero representa un importante nivel de correlación de larga distancia hacia los sedimentos deltaicos del noreste de México, conocidos como el Grupo Difunta.

Palabras Clave: ammonoides, bioestratigrafia, Cretácico, descripción sistemática, Maastrichtiano, México, paleobiogeografía. 


\section{Introduction}

Localities containing Maastrichtian ammonite assemblages are scarce in northeastern Mexico. In recent years, a series of publications have dealt with assemblages from new sites. The assemblages described show a strong bathymetric specialization for either explicitly shallow (Ifrim et al., 2005; Ifrim and Stinnesbeck, 2010) or deep water conditions (Ifrim et al., 2004, 2010).

Shallow water associations occur widely in the deltaic Difunta Group, a foreland basin to the uplifting Sierra Madre Oriental which covers most of eastern Chihuahua, Coahuila, and northwestern Coahuila. Sphenodiscus, Coahuilites and Baculites are present in this area and apparently were adapted to shallow coastal to marginally marine environments with reduced and changing salinities, temperature and agitated water (e.g. Ifrim et al., 2005; Ifrim and Stinnesbeck, 2010). In the Difunta Group, ammonoids other than the above described genera are extremely rare and only occur during sea level highstands in thin intervals of the succession. Occasionally, however, hemipelagic cephalopod assemblages and associated planktonic foraminifers are also present in the Difunta Group and in the transition to the coeval Mendez Formation. Recently, a diverse and abundant assemblage was discovered at La Parra, at approximately $20 \mathrm{~km}$ north of Saltillo, in the eastern Parras basin, and was assigned to the early Maastrichtian planktonic foraminiferal zone CF 5. This horizon provided an important level marker for correlation of the lower Difunta Group (Ifrim et al., 2010). East and south of Monterrey, in the states of Nuevo León and Tamaulipas, the Mendez Formation is coeval to the Difunta Group, and marls and shales in this area were deposited under open marine conditions. Faunal assemblages of the Mendez formation are hemipelagic and include abundant planktonic foraminifers, indicating water depths of over $100 \mathrm{~m}$ existed in the area of Cerralvo, $40 \mathrm{~km}$ east of Monterrey in the state of Nuevo Leon, and greater than 300 m east of Linares (Ifrim et al., 2004; Figure 1). The assemblage from Cerralvo is diverse ( 23 species referred to 18 genera) and indicates deposition in a pelagic environment during the early Maastrichtian biozone CF 7 of Li and Keller (1998a, 1998b), between 70.39 and 69.56 Ma; Sphenodiscus
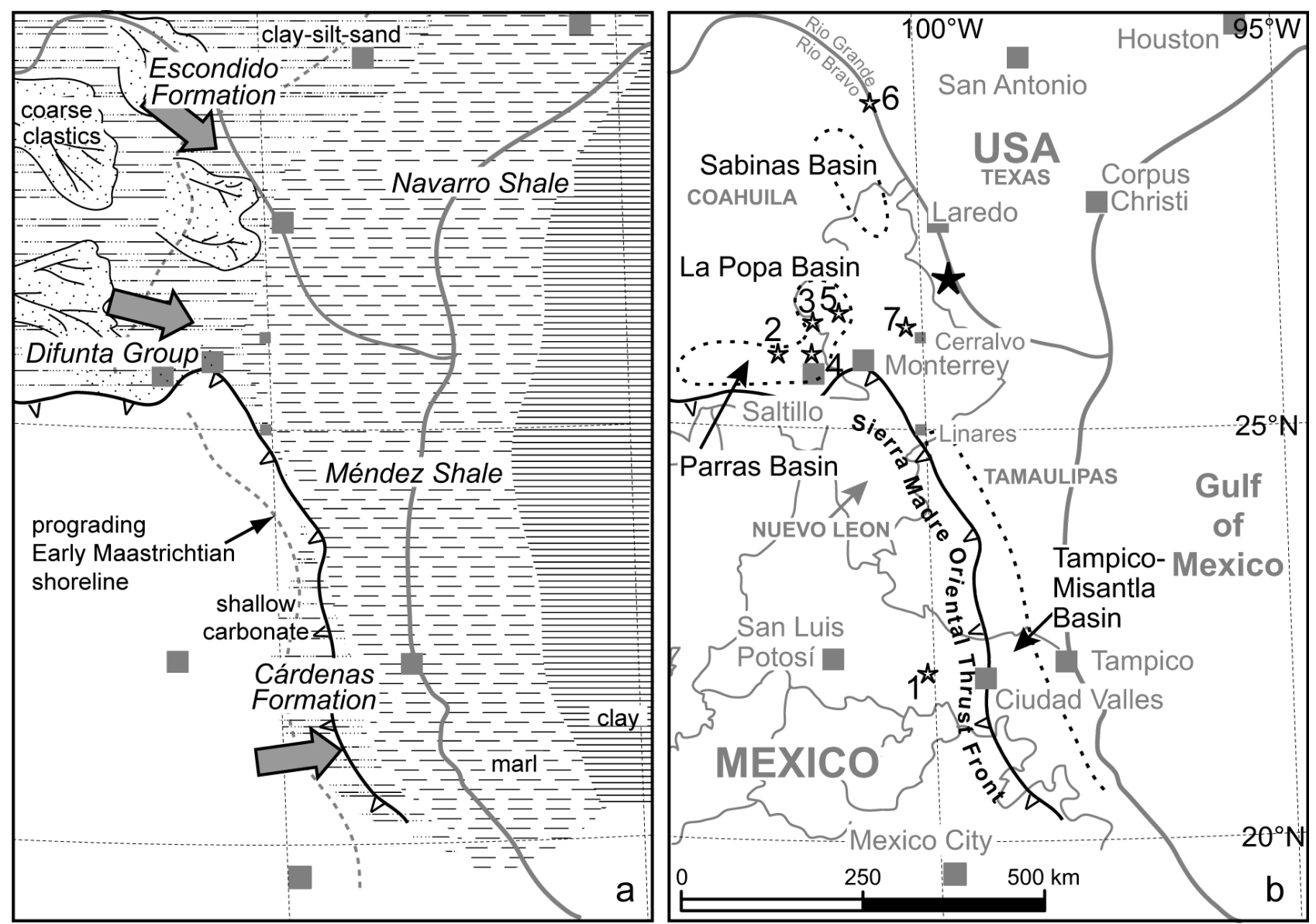

Figure 1. a: Paleogeographic lithofacies map of northeastern Mexico (modified after Goldhammer and Johnson, 2001; Soegaard et al., 2003) with coastline prograding from the northeast and east (after Weidie et al., 1972). b: Same map with geographic locations and paleogeographic elements, and northeastern Mexican ammonoid localities. 1: Cárdenas, San Luis Potosí; 2: Rincón Colorado, Coahuila, Parras Basin; 3: Reata, Coahuila, Parras Basin; 4: La Parra, Coahuila, Parras Basin; 5: Mina, NuevoLeón, Parras Basin; 6: Eagle Pass, Texas, Rio Grande Embayment; 7: Loma Los Martinitos, near Cerralvo, Nuevo León, open shelf; 8: El Zancudo, Tamaulipas. 
and Coahuilites are characteristically absent.

Here we report on a new ammonite assemblage which was discovered at El Zancudo, near Nuevo Laredo, Tamaulipas, in sediments of the proximal Mendez Formation. This assemblage is here interpreted in the context of the former data. It provides further insight into the many changes which occurred on the shelves of the western Gulf of Mexico during the Maastrichtian.

\section{The EI Zancudo locality}

The fossil-bearing locality was discovered in the late 1980s by geology student Humberto Garza García of the Facultad de Ciencias de la Tierra, Universidad Autónoma de Nuevo León at Linares, during field mapping for his licenciatura thesis in the area. He collected the ammonites in a single shale horizon within the Campanian-Maastrichtian Mendez Formation and donated the material to one of us (WS). According to his information, the fossil site, called "El Zancudo", is located approximately 70 kilometers south of Nuevo Laredo, Tamaulipas. It can be reached following Federal Highway 2 from Nuevo Laredo to Reynosa. Then a dirt roads lead towards the site west of the road, which is near $26^{\circ} 56^{\prime} 46.2^{\prime \prime} \mathrm{N}, 99^{\circ} 32^{\prime} 29.1^{\prime \prime} \mathrm{W}$. The lithology is marly and corresponds to the shales of the Mendez Formation.

Ammonites from El Zancudo are minute and reach maximum diameters of 18.1 millimeters $(\mathrm{mm})$. All specimens are phragmocones preserved as goethitized internal moulds. Pyritization produced a thin coat on the shells, which completely filled the chambers of small diameters. Pyrite was later oxidized by weathering.

During pyritization, larger chambers were left hollow and may have collapsed under lithologic overburden, thus explaining the absence of larger specimens and crushing of some shells with diameters greater than $10 \mathrm{~mm}$. The small sizes of El Zancudo ammonites apparently result from a preservational bias. This interpretation is supported by the fact that body chambers are not observed in El Zancudo ammonoids. A similar preservation was earlier observed in cephalopods from the Mendez Formation (Ifrim et al., 2004), $200 \mathrm{~km}$ to the southeast of El Zancudo, at Loma Los Martinitos, near Cerralvo (Figure 1), and $50 \mathrm{~km}$ north of Saltillo, at La Parra (Ifrim et al., 2010).

\section{Systematic Paleontology}

Ammonite assemblages of comparable size and their degree of preservation are known from northeastern Mexico in the Campanian-Maastrichtian Mendez Formation. These assemblages were described in detail by Ifrim et al. (2004, 2010). For taxa documented from these localities, we here refer to those publications regarding detailed species descriptions, synonymy lists and occurrences. Remarks are only added where necessary.
All 34 specimens collected at El Zancudo are registered and available at the Colección de Paleontología de Coahuila (CPC) at the Museo del Desierto, Saltillo, Coahuila, Mexico.

Linear dimensions are given in millimeters $(\mathrm{mm})$. Uncertain values due to deformation of the specimen and relations resulting from uncertain measurements are marked with an asterisk. Values in brackets refer to the proportion of the particular dimension to the whorl diameter. Abbreviations: D, diameter; WB, whorl width; $\mathrm{WH}$, whorl height; U, umbilical diameter; L, length between two measurements.

Systematic nomenclature of ammonoids follows the Treatise of Invertebrate Paleontology (Wright, 1996) to subspecies level, except for the genus Gaudryceras and the subgenus Anabrahmaites, for reasons discussed by Ifrim et al. (2004).

Order Ammonoidea von Zittel, 1884

Suborder Phylloceratina Arkell, 1950

Superfamily Phylloceratoidea von Zittel, 1884

Family Phylloceratidae von Zittel, 1884

Subfamily Phylloceratinae von Zittel, 1884

Genus Hypophylloceras Salfeld, 1924

Subgenus Hypohylloceras (Neophylloceras) Shimizu, 1934

\author{
Hypophylloceras (Neophylloceras) cf. H. (N.) surya \\ (Forbes, 1846) \\ Figures 2.1, 3a
}

2004 Hypophylloceras (Neophylloceras) cf. H. (N.) surya (Forbes); Ifrim et al., p. 1580, fig. 2c, 2d, 2e, 3a

Dimensions. CPC-585. D: 7.1, WB: 2.5 (0.35), WH 3.1 (0.44), WB/WH: 0.81, U: 1.5 (0.21)

Occurrence. Hypophylloceras (Neophylloceras) surya (Forbes) is a Maastrichtian species, with records from Madagascar (Collignon, 1956), South Africa (Kennedy and Klinger, 1976), Alaska, California, Japan (Ward and Kennedy, 1993), possibly the lower Maastrichtian of Mexico (Ifrim et al., 2004), and the upper Maastrichtian of southern India (Kennedy and Henderson, 1992), western Australia (Henderson and McNamara, 1985), the Biscay region (Ward and Kennedy, 1993), Denmark (Birkelund, 1993), Pakistan (Fatmi and Kennedy, 1999) and Chile (Stinnesbeck, 1986; Salazar et al., 2010).

Genus Phyllopachyceras Spath, 1927

Phyllopachyceras forbesianum (d'Orbigny, 1850)

Figures 2.2, 2.3, 3b, 3c

1846 Ammonites royanus Forbes, p. 108, pl. 8, fig. 6

1895 Phylloceras forbesianum (d'Orbigny), Kossmat, p. 109, pl. 15, fig. 1a, 1b, 1c (therein)

1970 Phyllopachyceras forbesianum (d'Orbigny), Henderson, p. 7, pl. 1, fig. 2, 4, 5 (with additional synonymy) 


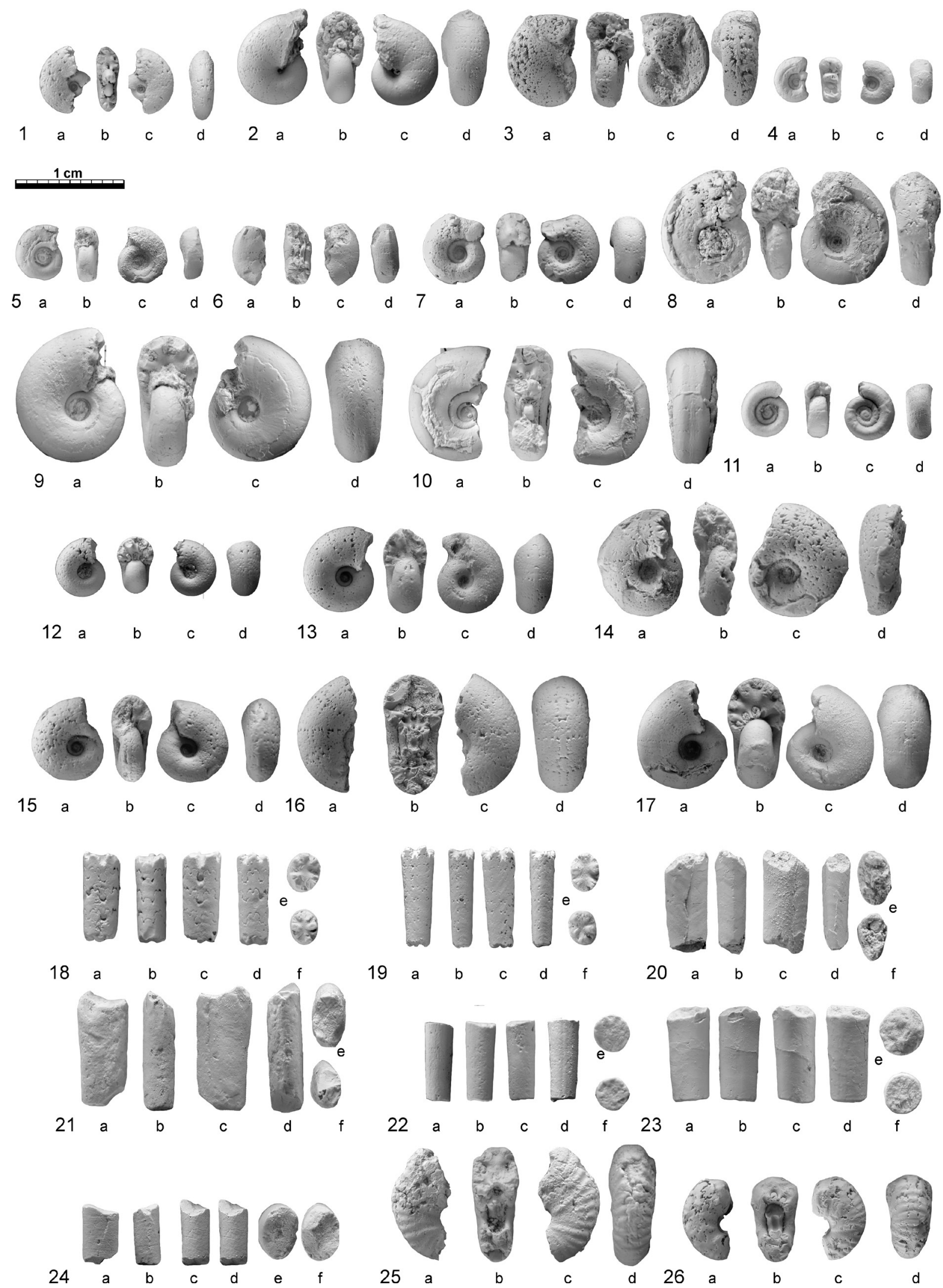

Figure 2. Ammonoids from El Zancudo. 1: Hypophylloceras (Neophylloceras) hetonaiense (CPC-585); 2-3: Phyllopachyceras forbesianum (2: CPC-586, 3: CPC-587); 4-10: Tetragonites superstes (4: CPC-589, 5: CPC-590, 6: CPC-591, 7: CPC-592, 8: CPC-593, 9: CPC-594, 10: CPC-595); 11: Gaudryceras kayei (CPC-588); 12-17: Brahmaites (Anabrahmaites) vishnu (12: CPC-596, 13: CPC-597, 14: CPC-598, 15: CPC-599, 16: CPC-640, 17: CPC-641); 18-21: Baculites ovatus (18: CPC-656; 19: CPC-654, 20: CPC-655, 21: CPC-657); 22-23: Fresvillia sp. (22: CPC-644, 23: CPC-647); 24: Diplomoceras cylindraceum (CPC-588); 25-26 Discoscaphites juv. sp. (25: CPC-642, 26: CPC-643).All x2. 
1992 Phyllopachyceras forbesianum (d'Orbigny), Kennedy and Henderson, p. 394; pl. 2, fig. 1-12; text-fig. $3 \mathrm{c}$ (with additional synonymy)

2004 Phyllopachyceras forbesianum (d'Orbigny), Ifrim et al., p. 1583; pl. 1, fig. 1-4; text-fig. 3b, 3c

2010 Phyllopachyceras forbesianum (d'Orbigny), Ifrim et al., p. 601; fig. 4r-y, 5c-d

Dimensions.

\begin{tabular}{cccccc}
\hline & $\mathrm{D}$ & WB & WH & WB/WH & U \\
\hline CPC-586 & 10 & $5.0(0.50)$ & $6.7(0.67)$ & 0.75 & $0.6(0.06)$ \\
CPC-587 & 18.1 & $* 7.0(* 0.39)$ & $10.6(0.59)$ & $* 0.66$ & $1.1(0.06)$ \\
\hline
\end{tabular}

Occurrence. Phyllopachyceras forbesianum is a cosmopolitan species and was recorded from the Santonian of Madagascar and the early Campanian of Spain. Records of Campanian-Maastrichtian ages are known from all latitudes (Alaska to the Antarctic Peninsula); this is the most widespread among the species described herein.

Suborder Lytoceratina Hyatt, 1900

Superfamily Tetragonitoidea Hyatt, 1900

Family Tetragonitidae Hyatt, 1900

Subfamily Tetragonitinae Hyatt, 1900

Genus Tetragonites Kossmat, 1895

Tetragonites superstes van Hoepen, 1921

Figures $2.4-2.10,3 \mathrm{~d}-3 \mathrm{j}$

1921 Tetragonites superstes van Hoepen, p. 10; pl. 2, fig. 17-20; fig. 6

1977 Tetragonites superstes van Hoepen; Kennedy and Klinger, p. 162, fig. 7a-7d, 7h-7j, 8, 12a-12c

2004 Tetragonites superstes van Hoepen; Ifrim et al., p. 1584, pl. 1, fig. 5-8; Figures 3e-g

2010 Tetragonites superstes van Hoepen; Ifrim et al., p. 602, fig. 4z-4kk

Dimensions.

\begin{tabular}{cccccc}
\hline & $\mathrm{D}$ & $\mathrm{WB}$ & $\mathrm{WH}$ & WB/WH & $\mathrm{U}$ \\
\hline CPC-589 & 4.7 & $2.3(0.49)$ & $1.8(0.38)$ & 1.28 & $1.4(0.30)$ \\
CPC-590 & $* 5.6$ & $* 2.4(0.43)$ & $* 2.5(0.45)$ & 0.96 & $2.0(0.36)$ \\
CPC-591 & $* 8.5$ & $* 3.4(0.40)$ & $* 4.0(0.47)$ & 0.85 & - \\
CPC-592 & 6.6 & $3.3(0.50)$ & $3.5(0.53)$ & 0.94 & $1.8(0.27)$ \\
CPC-593 & 9.2 & $4.3(0.47)$ & $* 4.7(0.51)$ & 0.91 & $2.4(0.26)$ \\
CPC-594 & 13 & $6.0(0.46)$ & $5.8(0.45)$ & 1.03 & $2.5(0.19)$ \\
CPC-595 & 12.4 & $6.6(0.53)$ & $5.3(0.43)$ & 1.25 & $3.1(0.25)$ \\
\hline
\end{tabular}

Occurrence. Tetragonites superstes van Hoepen is known from the late Santonian or early Campanian of South Africa (Kennedy and Klinger, 1977), the early to middle Campanian of Madagascar (Collignon, 1956), and the early Maastrichtian of north-eastern Mexico (Ifrim et al., 2004, 2010).

Family Gaudryceratidae Spath, 1927 Genus Gaudryceras de Grossouvre, 1894
Gaudryceras kayei (Forbes, 1846)

Figure 2.11

1846 Ammonites kayei Forbes, p. 101; pl. 8, fig. 3

1906 Gaudryceras kayei (Forbes), Woods, p. 335; pl. 41, fig. 8; pl. 42, fig. 1

1979 Vertebrites kayei (Forbes), Kennedy and Klinger, p. 160; fig. 5; pl. 14, fig. 2 (with full synonymy)

1985 Gaudryceras kayei (Forbes), Henderson and McNamara, p. 46; pl. 1, fig. 9,10; text-fig. 4d

2004 Gaudryceras kayei (Forbes), Ifrim et al., p. 1589; fig. 31-3n, 5d, 6a-6c, 6h

2010 Gaudryceras kayei (Forbes), Ifrim et al., p. 603; fig. 4tt-4aaa, 5g, 5h

Dimensions. CPC-588. D: 5.3, WB: 2.5 (0.47), WH: $1.6(0.30), \mathrm{WB} / \mathrm{WH}: 1.56, \mathrm{U}: 2.3$ (0.43).

Occurrence. The species is known from Santonian to Maastrichtian strata, and has been described from South Africa (Woods, 1906; Kennedy and Klinger, 1979), Tunisia (Pervinquière, 1907), the Biscay region (Ward and Kennedy, 1993), Pakistan (Fatmi and Kennedy, 1999), southern India (Kennedy and Henderson, 1992), western Australia (Henderson and McNamara, 1985), Chile (Stinnesbeck, 1986), California (Matsumoto, 1959), and Madagascar (Collignon, 1956), among other localities. The Santonian record of Böse (1928) from north-eastern Mexico was put into doubt by Ifrim et al. (2004), but these authors described specimens from the early (2004) and middle (2010) Maastrichtian of this region.

Suborder Ammonitina Hyatt, 1889

Superfamily Desmoceratoidea Zittel, 1895

Family Kossmaticeratidae Spath, 1922

Subfamily Kossmaticeratinae Spath, 1922

Genus Brahmaites Kossmat, 1897

Subgenus Brahmaites (Anabrahmaites) Yabe and Shimizu, 1924

Brahmaites (Anabrahmaites) vishnu (Forbes, 1846) Figures 2.12-2.17, 3k-3p

1846 Ammonites vishnu Forbes, 1846, p. 100; pl. 7, fig. 9 1992 Brahmaites (Anabrahmaites) vishnu (Forbes, 1846); Kennedy and Henderson, p. 418; pl. 6, fig. 25, 26; pl. 9, fig. 5-7, 17-20; pl. 10, fig. 5; pl. 17, fig. 8, 10, 11 (with full synonymy)

1993 Brahmaites (Anabrahmaites) vishnu (Forbes 1846), Kennedy and Hancock, p. 580; pl. 1, fig. 5, 6

2004 Brahmaites (Anabrahmaites) vishnu (Forbes 1846), Ifrim et al., p. 1600; fig. 8a, 8b, 9a-9d

2010 Brahmaites (Anabrahmaites) vishnu (Forbes 1846), Ifrim et al., p. 607; fig. 5n-5p, 7iii-7xxx, 9

Material. Six internal moulds of juveniles. 

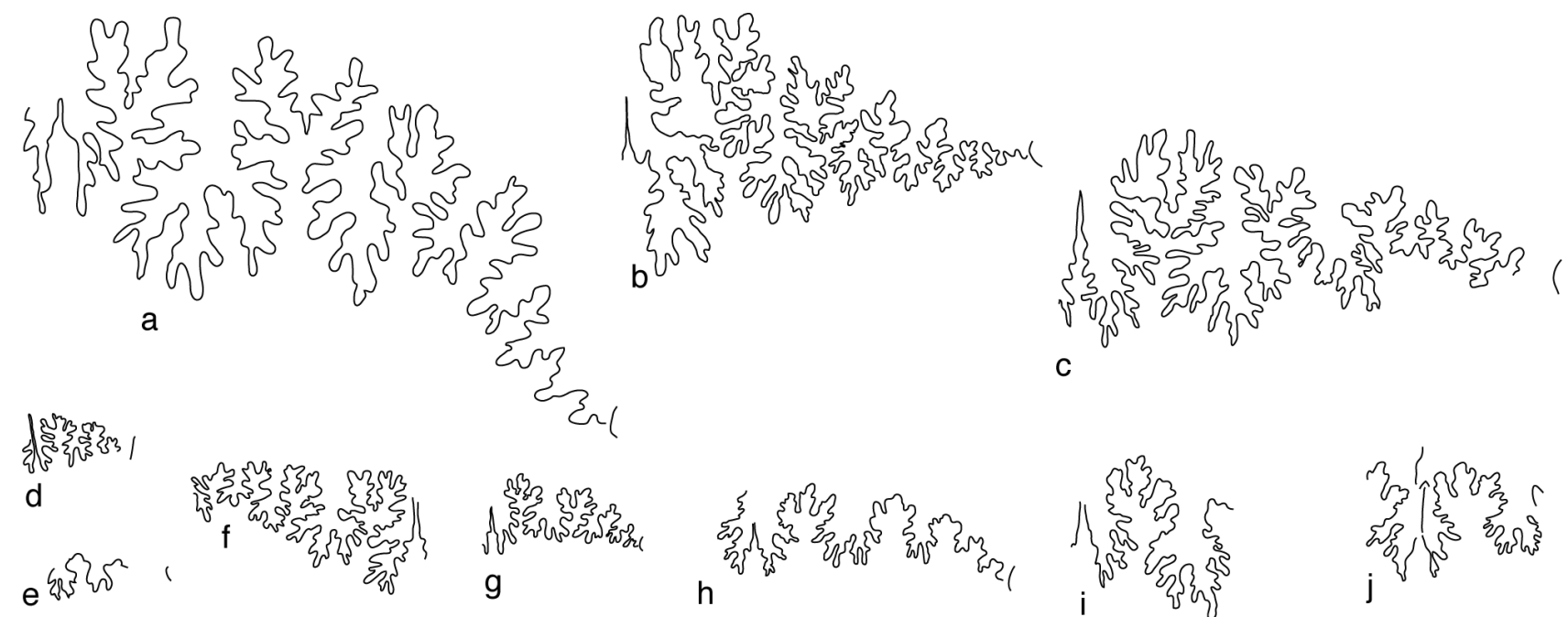

$\mathrm{h}$
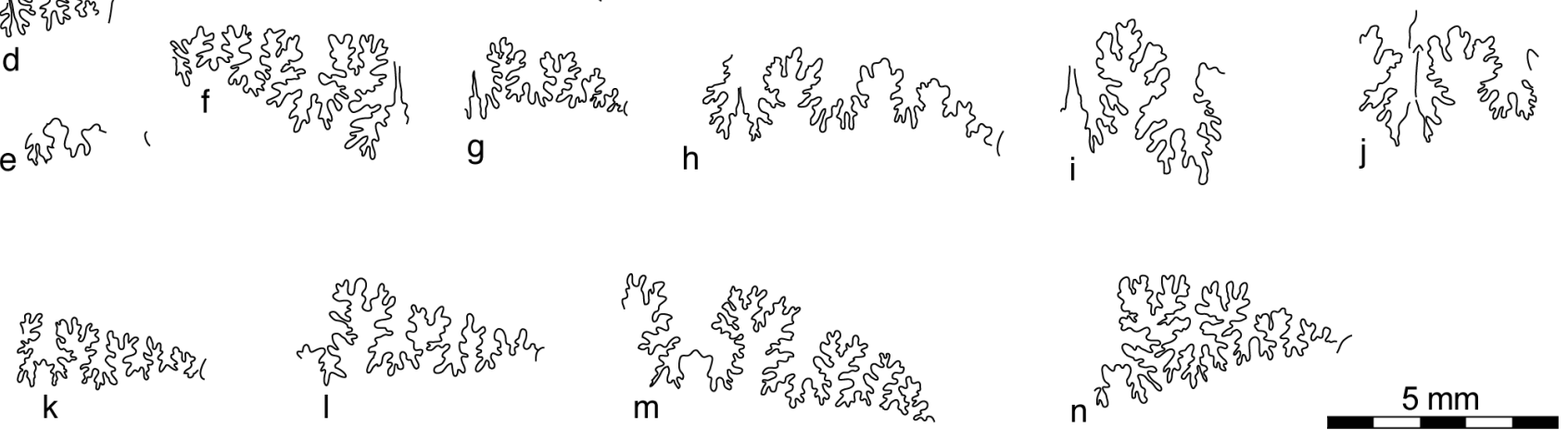

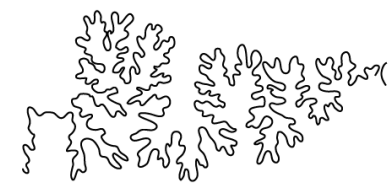

0

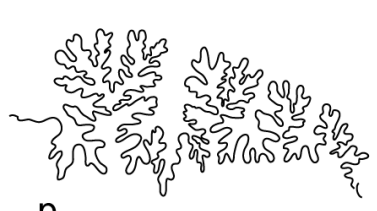

$p$

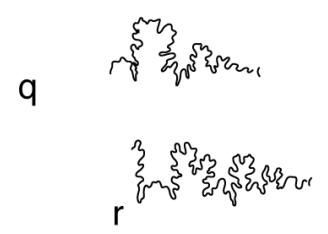

Figure 3. Suture lines of ammonoids from El Zancudo. a: Hypophylloceras (Neophylloceras) surya (CPC-585); b-c: Phyllopachyceras forbesianum (b: CPC-586, c: CPC-587); d-j: Tetragonites superstes (d: CPC-588, e: CPC-589o590, f: CPC-591, g: CPC-592, h: CPC-593, i: CPC-594, j: CPC-595); k-p: Brahmaites (Anabrahmaites) vishnu (Forbes, 1846) (k: CPC-596, 1: CPC-597, m: CPC-598, n: CPC-599, o: CPC-640, p: CPC-641); q-r: Discoscaphites juv. sp. (q: CPC-642, r: CPC-643); s-t: Baculites (s: CPC-654. t: CPC-656). All x5.

\section{Dimensions.}

\begin{tabular}{|c|c|c|c|c|c|}
\hline & D & WB & WH & WB/WH & U \\
\hline СРC-596 & 5.5 & $3.5(0.64)$ & $2.8(0.51)$ & 1.25 & $1.2(0.22)$ \\
\hline СРC-597 & 8 & $* 3.6(* 0.45)$ & $4.2(0.53)$ & $* 0.86$ & $1.7(0.21)$ \\
\hline СРC-598 & 8.9 & $4.4(0.49)$ & $4.4(0.49)$ & 1 & $2.0(0.22)$ \\
\hline СРC-599 & 9.1 & $* 2.6(* 0.29)$ & $* 3.0(* 0.33)$ & $* 0.87$ & $2.2(0.24)$ \\
\hline CPC-640 & 12 & $6.0(0.50)$ & $5.3(0.44)$ & 1.13 & $* 2.2(* 0.18)$ \\
\hline СРC-641 & 11.3 & $6.0(0.53)$ & $5.6(0.50)$ & 1.07 & $2.6(0.23)$ \\
\hline
\end{tabular}

Occurrence. Brahmaites (Anabrahmaites) vishnu (Forbes, 1846), occurs in the Maastrichtian of southern India (Kennedy and Henderson, 1992), Armenia (Atabekian and Akopian, 1970), Madagascar (Collignon, 1938), southwestern France and northern Spain (Ward and Kennedy, 1993). In the Gulf of Mexico area, the genus Brahmaites was first described by Cobban and Kennedy (1991) from the Nacatotch Sand, Arkansas, but these specimens have not been determined to species level. In contrast, Ifrim et al. (2004, 2010) documented abundant $B$. (A.) vishnu from the early and early-late Maastrichtian of north-eastern Mexico.
Suborder Ancyloceratina Wiedmann, 1966

Superfamily Turrilitoidea Gill, 1871

Family Baculitidae Gill, 1871

Genus Baculites Lamarck, 1799

Baculites ovatus Say, 1820

Figures 2.18-2.21, 3s, 3t

1820 Baculites ovata Say, p. 41

1974 Baculites ovatus Say, Cobban, p. 3; pl. 1, fig. 1-31; pl. 2, fig. 1-14; pl. 3, fig. 1-6, 9-11; text-fig. 4 (with full synonymy)

2004 Baculites ovatus Say, Ifrim et al., p. 1601; pl. 3, fig. 1-3; text-fig. 11a-11e, 12a-12d

2005 Baculites ovatus Say, Ifrim et al., p. 58; fig. 5i, 5j, $9 d-91$

2010 Baculites ovatus Say, Ifrim et al., p. 608; fig. 5y, $5 \mathrm{z}, 10 \mathrm{a}-10 \mathrm{v}$

Occurrence. Baculites ovatus Say is known to occur in the late Campanian of New Jersey (Cobban, 1974), the 
Maastrichtian of Arkansas (Kennedy and Cobban, 1993a) and Mexico (Ifrim et al., 2004; Ifrim et al., 2005; Ifrim and Stinnesbeck, 2010; Ifrim et al., 2010). Records may also exist from Palestine and Egypt.

Genus Fresvillia Kennedy, 1986b

Fresvillia sp. indet.

Figure 2.24-2.29

\section{Dimensions.}

\begin{tabular}{ccccc}
\hline & WB & WH & WB/WH & L \\
\hline \multirow{2}{*}{ CPC-646 } & 2.1 & 2.2 & 0.95 & 7.1 \\
& 2.7 & 2.7 & 1 & \\
CPC-645 & 2.4 & 2.4 & 1 & 7.2 \\
& 3 & 3.1 & 0.97 & \\
CPC-649 & 2.4 & 2.5 & 0.96 & 8.9 \\
& 3.2 & 3 & 1.07 & \\
CPC-644 & 2.5 & 2.6 & 0.96 & 7.4 \\
& 3 & 3 & 1 & \\
CPC-650 & 2.8 & 2.9 & 0.97 & 8 \\
& 3.7 & 3.4 & 1.09 & \\
CPC-651 & 3.1 & 3.3 & 0.94 & 6.4 \\
& 3.9 & 4.2 & 0.93 & \\
CPC-648 & 3.3 & 3.5 & 0.94 & 5.6 \\
& 3.5 & 3.9 & 0.9 & \\
CPC-647 & 4.1 & 4 & 1.03 & 7.4 \\
& 4.7 & 4.5 & 1.04 & \\
\hline
\end{tabular}

Remarks. The circular whorl section and the simple suture line with triangular elements of similar height and shape distinguish Fresvillia from Baculites. Specimens described here have completely smooth surfaces lacking the distant constrictions of $F$. constricta. Fresvillia teres (Forbes) differs from $F$. constricta in the presence of faint annular to ventrally prorsiradiate ribs which are equally strong around the shell, whereas the constrictions in $F$. constricta are most pronounced dorsally. No ornament is preserved, and the specimens thus cannot be related to any of the two species.

Occurrence. Fresvillia is a rare Maastrichtian genus, with records from France, South Africa, India, western Australia, Alaska, Mexico, and California (Wright, 1996; Ifrim et al., 2004, 2010).

Family Diplomoceratidae Spath, 1926

Subfamily Diplomoceratinae Spath, 1926

Genus Diplomoceras Hyatt, 1900

Type species. Baculites cylindraceus Defrance (1816, p. 160), by original designation. For a description of the genus see Olivero and Zinsmeister (1989), for occurrence see Kennedy (1986a).

Diplomoceras cylindraceum (Defrance, 1816)

Figure 2.30

1816 Baculites cylindracea Defrance, p. 160 1986a Diplomoceras cylindraceum (Defrance), Kennedy, p. 181; pl. 17, fig. 3; pl. 18, fig. 5; pl. 21, fig. 2, $3,5,6$; pl. 22 , fig. 6 ; pl. 23 , fig. 1,2 ; pl. 24 , fig. $1-3$; pl. 25 , fig. 1-8; pl. 26, fig. 18; pl. 33, fig. 16; pl. 36, fig. 6; text-fig. 9,10 (with full synonymy)

1986b Diplomoceras cylindraceum (Defrance), Kennedy, p. 51; pl. 4, fig. 1, 2; pl. 9, fig. 8-10; pl. 10; textfig. 3i-31, 6, 7g-7m (with full synonymy)

2004 Diplomoceras cylindraceum (Defrance), Ifrim et al., p. 1607; text-fig. 13g, 13h, 14e

2010 Diplomoceras cylindraceum (Defrance), Ifrim et al., p. 610, fig. 10uu-10zz

Dimensions. CPC-658. WB: 4.7, WH: 6.5, WB/WH: 0.72, L: 4.9. WB: 4.6, WH: 6.7, WB/WH: 0.69 .

Occurrence. Diplomoceras cylindraceum was recorded throughout the Maastrichtian and is known in all latitudes from Alaska to Antarctica.

Superfamily Scaphitoidea Gill, 1871

Family Scaphitidae Gill, 1871

Subfamily Scaphitinae Spath, 1926

Genus Discoscaphites Meek, 1871

Type species. Ammonites conradi Morton (Morton, 1834, p. 39), by original designation.

Discoscaphites juv. sp.

Figures 2.25, 2.26, 3q, 3r

Material. Two juvenile specimens, CPC-642 and CPC643.

Description. Moderately involute, with moderate expansion rate. Whorl section is rounded to slightly compressed. The umbilicus is small and deep. The umbilical wall is narrowly rounded and grades into widely rounded convergent flanks. Maximum whorl breadth is near the umbilicolateral part of the flank. Ventrolaterally, rounding is more narrow and a shoulder is formed, which transits into a widely rounded, almost flat venter. Three primary ribs per half whorl arise from the umbilicus. They are straight and slightly prorsiradiate. In CPC-643, the larger specimen, they thicken ventrolaterally to form low tubercles, which are absent in the smaller specimen CPC-642. Three to four secondary ribs arise laterally between two primaries; they are parallel to the primaries and form ventrolateral tubercles in the same position than the tubercles on the primary ribs. In both specimens, the ribs cross the venter in a straight line. The suture line is moderately incised, with $\mathrm{U} / \mathrm{L}$ being asymmetrically bifid, and L asymmetrically trifid.

Dimensions.

\begin{tabular}{cccccc}
\hline & $\mathrm{D}$ & $\mathrm{WB}$ & $\mathrm{WH}$ & $\mathrm{WB} / \mathrm{WH}$ & $\mathrm{U}$ \\
\hline $\mathrm{CPC}-642$ & 8.6 & $5.0(0.58)$ & $* 4.8(* 0.56)$ & $* 1.04$ & $1.8(0.21)$ \\
CPC-643 & $* 12.0$ & $5.0(* 0.42)$ & $6.6(* 0.55)$ & 0.76 & $1.9(* 0.16)$ \\
\hline
\end{tabular}

Remarks. The present juvenile Scaphitinae are difficult to determine. This is due to the fact that many of the specimens figured in the current literature are too large to be compared with our material, but it is also a result of 
the important changes in shell morphology during early ontogeny. Five ontogenetic growth stages are documented for genera of Maastrichtian Scaphitinae. The most detailed study was carried out by Landman and Waage (1993), who documented specimens of several genera and species with diameters comparable to our material. At these small diameters, tuberculation is occasionally present, but not fully developed yet. The ribs of Jeletzkytes are much coarser than in our individuals, and sigmoidal instead of straight. More primary and less secondary ribs are present. Moreover, the umbilicus of Jeletzkytes is much larger at comparable growth stages. In juvenile Hoploscaphites the umbilicus is also much larger. In addition, more primary and less secondary ribs are developed than in our individuals, and the ribs bend forward to cross the venter in a wide arch. The whorl relations and ribbing pattern of juvenile Discoscaphites are closest to our specimens. However, the shell in $D$. conradi is more compressed than in our specimens, whereas $D$. gulosus and D. rossi have coarser and finer ribs, respectively. Our material compares well with juveniles of $D$. iris (compare e.g. Kennedy and Cobban, 2000, pl.3, fig. 33; Landman et al., 2004a, fig. 34a-d, s). and D. minardi (Kennedy and Cobban, 2000, pl. 1, fig. 2-4), but precise determination of the species is not possible at the moment.

Occurrence. The genus Discoscaphites is present in North America from the middle to the upper Maastrichtian (Landman et al., 2004b) and is known from the Western Interior Seaway, the northern Gulf of Mexico and the Atlantic Coast. Records outside North America are from the upper Maastrichtian, e.g. an isolated specimen of $D$. iris was recorded from the uppermost Maastrichtian of Libya (Machalski et al., 2009); an undeterminable specimen of Discoscaphites of late Maastrichtian age, but unknown stratigraphic origin, from South Africa (Klinger and Kennedy, 2005); Discoscaphites gulosus from Bulgaria; and Discoscaphites sp. indet. from Denmark and Sweden (Machalski et al., 2007).

\section{Interpretation of the cephalopod assemblage from El Zancudo}

\subsection{Biostratigraphy}

Phyllopachyceras forbesianum, Tetragonites superstes and Gaudryceras kayei are long-lasting, conservative species which are known from at least the Campanian and Maastrichtian.

Hypophylloceras (Neophylloceras) surya is an exclusively Maastrichtian species, with most records restricted to the late Maastrichtian. The specimens assigned to Fresvillia cannot be determined further, but the genus is also restricted to the Maastrichtian. Baculites ovatus already exists in the late Campanian, but not in northeastern Mexico, to which it immigrated during the early Maastrichtian (Ifrim and Stinnesbeck, 2010; Ifrim et al., 2010). Diplomoceras cylindraceum was recorded throughout the Maastrichtian and is known in all latitudes from Alaska to Antarctica. Discoscaphites, now documented for the first time for Mexico, restricts the age of the assemblage to the lowerupper, or upper Maastrichtian.

The age of the El Zancudo ammonite association can be further restricted by comparing the faunal composition to other assemblages described from northeastern Mexico. The species of these other assemblages are listed in Table 1 for comparison. For instance, the Zancudo fauna differs from the early Maastrichtian Cerralvo fauna in the absence of Nostoceras. Nostoceratids became extinct during the middle Maastrichtian (Goolaerts, 2010).

The similarity of the El Zancudo ammonite assemblage with that of La Parra, Coahuila, leads to the interpretation that they are of similar age. The Zancudo fauna include the cold-water species Tetragonites superstes, which immigrated from the southern hemisphere during a Maastrichtian cooling event in the late early Maastrichtian (biozone CF 7, Ifrim et al., 2004). In addition, Nostoceras is missing, showing that the assemblage formed after the extinction of this genus in the middle Maastrichtian. Ammonoids declined considerably during the late Maastrichtian in Mexico, as summarized by Stinnesbeck et al. (2012), but this is not recognized in the El Zancudo assemblage. We therefore conclude that this assemblage must be slightly older and the fauna is of early-late Maastrichtian age.

\subsection{Stratigraphic implications}

Correlations within the Late Cretaceous part of the Difunta Group are mostly isolated and tentative, including correlation with other coeval deep water and marginal marine deposits within Mexico (e.g., Cárdenas Formation in central-eastern Mexico, Schafhauser et al., 2007; Mendez Formation in eastern Mexico, Stinnesbeck et al., 1996), and with global sea-level changes (Lawton et al., 2001; Soegaard et al., 2003; Aschoff and Giles, 2005) as a result of the near-absence of age-diagnostic fossils in this deltaic complex. The ammonite assemblage collected at El Zancudo in the Mendez Formation thus opens a rare opportunity for correlation between shallow and deep water regimes in the region.

The Maastrichtian assemblages from Texas formerly described differ significantly in their composition compared to the El Zancudo assemblage, but also from each other. A shallow water assemblage, composed of Sphenodiscus and Coahuilites, has been described from the siliciclastic complex of the Escondido Formation (Cooper, 1970). This can be explained by the deltaic facies in which the assemblage was found. Another assemblage from northeastern Texas comprises the species Baculites columna, Discoscaphites conradi, Eubaculites carinatus, Glyptoxoceras, Jeletzkytes, Nostoceras major, Sphenodiscus lobatus, S. pleurisepta, and Trachyscaphites yorkensis (Kennedy and Cobban, 
1993b). This assemblage is early Maastrichtian in age, which partially explains the different composition of the fauna. Another Texan assemblage was described from the $\mathrm{K} / \mathrm{Pg}$ boundary sediments near Brazos. It is composed of Discoscaphites cf. gulosus, D. sphaeroidalis, Eubaculites carinatus, Pachydiscus cf. jacquoti and Glyptoxoceras cf. rugatum. These are the last ammonites found below the $\mathrm{K} /$ $\mathrm{Pg}$ boundary, i.e. this assemblage is younger and includes the youngest ammonites found in Texas (Kennedy et al., 2001). Correlation of sedimentary units in Mexico is thus problematic. The similarity of the El Zancudo assemblage to the Mexican deep-water faunas now provides a further stratigraphic level marker.

\subsection{Paleobiogeographical interpretation}

The definition of provincialism follows that of Ifrim et al. (2004). The Zancudo assemblage contains faunal elements of three distinct paleobiogeographical provinces.

a) Tethyan elements sensu latu, including boreal and the southern mid-latitude species, are recognized in Tetragonites superstes and Baculites ovatus (see Ifrim et al., 2010, for discussion).

b) Cosmopolitan species Gaudryceras kayei, Diplomoceras cylindraceum and Phyllopachyceras forbesianum are known to have a worldwide distribution.

c) Cold water species. They occur in the southern high latitudes, including the Antarctic shelf, and in the northern Pacific. Neophylloceras (Hypophylloceras) surya is a member of this group.

In their description of a slightly older assemblage from the Mendez Formation near Cerralvo, Ifrim et al. (2004) distinguished a fourth group of "species endemic to North America". This group contained three species of Nostoceras, not present at El Zancudo.

The two fragments of Discoscaphites juv. sp. are difficult to classify. The genus was only known from North America until the description of an isolated fragment form the uppermost Maastrichtian of Libya (Machalski et al., 2009), Bulgaria, Denmark and Sweden (Machalski et al., 2007). However, these records differ in age and are scattered. In addition, our specimens are not determined to species level. Discoscaphites juv. sp. is thus left out of the palaeogeographic interpretation.

Table 1. Distribution of species in north-eastern Mexican cephalopod assemblages. Numbers are specimens registered at the site. Question marks indicate species in open nomenclature. Specimens from shallow water environments are from different localities, each of which contained too few specimens for quantitative analysis. They are C: Cárdenas, San Luis Potosí; EP: Escondido Formation, near Eagle Pass, Texas; M: Mina, Nuevo León; R: Reata, Coahuila; RC; Rincón Colorado, Coahuila; S: Saltillo, Coahuila. These localities are presented in Figure 1. Data outside El Zancudo from Ifrim et al. $(2004,2005,2010)$.

\begin{tabular}{|c|c|c|c|c|c|}
\hline & $\begin{array}{r}\text { locality } \\
\text { facies }\end{array}$ & $\begin{array}{c}\text { El Zancudo } \\
\text { pelagic-neritic }\end{array}$ & $\begin{array}{c}\text { Cerralvo } \\
\text { pelagic }\end{array}$ & $\begin{array}{c}\text { La Parra } \\
\text { deep neritic }\end{array}$ & $\begin{array}{c}\text { near coast } \\
\text { shallow water }\end{array}$ \\
\hline \multirow{6}{*}{ North America } & Coahuilites sheltoni & - & - & - & C M S \\
\hline & Nostoceras ( $N$. ) alternatum & - & 108 & - & - \\
\hline & $N .(N$.$) colubriformis$ & - & 108 & - & - \\
\hline & $N .(N$.$) rugosum$ & - & 66 & - & - \\
\hline & Sphenodiscus lobatus & - & - & - & $\mathrm{RC}$ \\
\hline & Sphenodiscus pleurisepta & - & - & - & C EP R \\
\hline \multirow{8}{*}{ Tethyan and Boreal } & Baculites ovatus & $? 6$ & 167 & 137 & $\mathrm{M}$ \\
\hline & Brahmaites (Anabr.) vishnu & 6 & 83 & 127 & - \\
\hline & Fresvillia constricta & & 22 & 10 & - \\
\hline & Hauericeras rembda & - & 35 & 2 & - \\
\hline & Pachydiscus $(P$.$) neubergicus$ & - & $? 60$ & $? 30$ & $\mathrm{C}$ \\
\hline & Solenoceras reesidei & - & 15 & 3 & - \\
\hline & Solenoceras texanum & - & 13 & - & - \\
\hline & Tetragonites superstes & 7 & 27 & $? 15$ & - \\
\hline \multirow{6}{*}{ cosmopolitan } & Anagaudryceras politissimum & - & 27 & 3 & - \\
\hline & Desmophyllites diphylloides & - & 18 & 17 & - \\
\hline & Diplomoceras cylindraceum & 1 & 3 & 3 & - \\
\hline & Gaudryceras kayei & 1 & 53 & 68 & - \\
\hline & Phyllopachyceras forbesianum & 2 & 104 & 40 & - \\
\hline & Pseudophyllites indra & - & 9 & 9 & - \\
\hline \multirow{6}{*}{ cold water } & Fresvillia teres & 8 & $? 8$ & 10 & - \\
\hline & Hypophylloceras (Neophylloceras) surya & 1 & $? 6$ & $? 4$ & - \\
\hline & H. $(N$.$) hetonaiense$ & - & 20 & 6 & - \\
\hline & Naefia neogaeia & - & 4 & - & - \\
\hline & Pachydiscus $(P$.$) egertoni$ & - & - & $? 79$ & - \\
\hline & Zelandites varuna & - & 9 & - & - \\
\hline \multirow{5}{*}{ undefined } & Eutrephoceras sp. & - & - & 1 & - \\
\hline & Menuites juv. sp. & - & 42 & 36 & - \\
\hline & Saghalinites cala & - & 1 & - & - \\
\hline & Discoscaphites juv. sp. & $? 2$ & - & - & - \\
\hline & SUM & 34 & 1008 & 602 & - \\
\hline
\end{tabular}




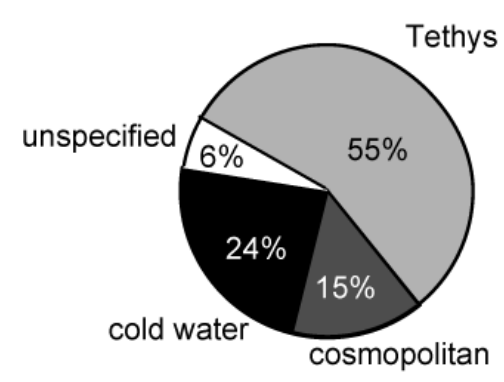

Zancudo $(n=34)$

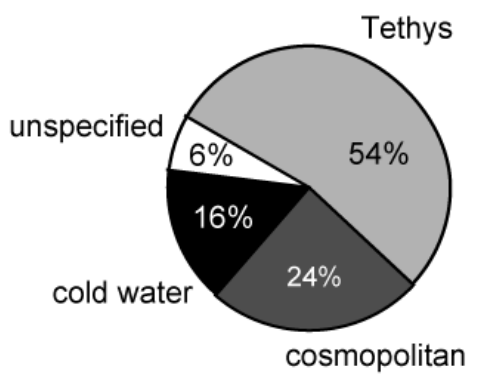

La Parra $(n=602)$

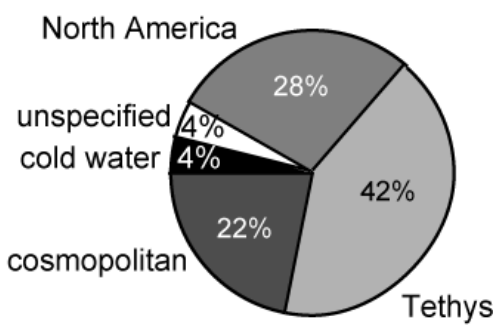

Cerralvo $(n=1008)$

Figure 4. Paleobiogeographical distribution of the El Zancudo, La Parra and Cerralvo ammonoid assemblages. The category "unspecified" in the El Zancudo assemblage includes the specimens of Discoscaphites, which may also be classified as "North American". Data after Ifrim et al. (2004, 2010), and Table 1 herein. Note the similarities between the El Zancudo and La Parra assemblages despite the small data set at El Zancudo ( $\mathrm{n}=34)$, and their difference to the Cerralvo assemblage.

Results regarding the paleobiogeographical interpretation of the La Parra ammonoid assemblage are summarized in Table 1. According to these data, the assemblage is composed of $55 \%$ Tethyan, $15 \%$ cosmopolitan, $24 \%$ cold water, and $6 \%$ unclassified specimens (Figure 4).

The paleobiogeographical composition is thus strikingly similar to that of La Parra in Coahuila, $c a .200 \mathrm{~km}$ southwest of Nuevo Laredo. It differs from the Cerralvo fauna, which contains 28 per cent North American ammonoids, all related to Nostoceras, which was already extinct by the time the La Parra and El Zancudo assemblages were deposited. However, proportions of the categories "cosmopolitan", "Tethyan" and "cold water", relative to each other at Cerralvo, are also comparable to La Parra and El Zancudo.

\section{Conclusions}

The small collection of ammonoids from El Zancudo, a locality near Nuevo Laredo, Tamaulipas, contains eight taxa, seven of which were previously known from northeastern Mexico. The assemblage is similar to a fauna from La Parra, near Saltillo, Coahuila, > $200 \mathrm{~km} \mathrm{SSW}$ of Nuevo Laredo, and indicates that taxa present in both localities inhabited a broad region on the western Gulf of Mexico shelf. The assemblage at El Zancudo differs from other ammonoid assemblages described before from Texas and Mexico due to formation at different ages or in facies. The El Zancudo assemblage provides an important biostratigraphic marker level for correlation of deeper facies to the shallow water sediments of northeastern Mexico.

\section{Acknowledgments}

Humberto Garza García is acknowledged for donating the El Zancudo ammonoids to WS in the late 1980s. Arturo H. González González (Museo del Desierto) provided logistical support and José M. Padilla Gutierrez (Museo del Desierto) provided access to the CPC collection. Permission of temporary export of the fossil material by
Instituto Nacional de Antropología e Historia (INAH) Coahuila, and financial support by the State Foundation of Baden-Württemberg (Brigitte-Schlieben-Lange-Program) are gratefully acknowledged.

\section{References}

Aschoff, J.L., Giles, K.A., 2005, Salt diapir-influenced, shallow-marine sediment dispersal patterns: Insights from outcrop analogs: American Association of Petroleum Geologists Bulletin, 89, 447-469.

Atabekian, A.A., Akopian, V.T., 1970, Late Cretaceous ammonites of the Armenian SSR (Pachydiscidae, Kossmaticeratidae and Scaphitidae): Proceedings of the Armenian Academy of Science, Earth Sciences, 5, 31-42, [in Georgian].

Arkell, W.J., 1950, A classification of the Jurassic ammonites: Journal of Paleontology, 24, 354-364.

Birkelund, T., 1993, Ammonites from the Maastrichtian White Chalk in Denmark: Bulletin of the Geological Society of Denmark, 40, 33-81.

Böse, E., 1928, Cretaceous ammonites from Texas and northern Mexico: University of Texas Bulletin, 2748, 143-357, plates 1-18.

Cobban, W.A., 1974, Ammonites from the Navesink Formation at Atlantic Highlands, New Jersey: Washington, D.C., United States Geological Survey, Professional Paper 845, 46 p., 11 plates.

Cobban, W.A., Kennedy, W.J., 1991, Some Upper Cretaceous ammonites from the Nacatoch Sand of Hempstead County, Arkansas: United States Geological Survey Bulletin, 1985, 1-5, 1 plate.

Collignon, M., 1938, Ammonites Campaniennes et Maastrichtiennes de l'ouest et du sud de Madagascar: Annales Géologiques du Service des Mines de Madagascar, 9, 55-118.

Collignon, M., 1956, Ammonites néocrétacées du Menabe (Madagascar) IV.-Les Phyllocératides; V.-Les Gaudrycératides; VI.-Les Tetragonitidae: Annales géologiques du Service des Mines de Madagaskar, 23, 1-106.

Cooper, J.D., 1970, Stratigraphy and paleontology of Escondido Formation (Upper Cretaceous), Maverick County, Texas, and northern Mexico: Austin, Texas, University of of Texas, $\mathrm{PhD}$ thesis, $288 \mathrm{p}$.

Defrance, M.J.L., 1816, [passim], in Defrance, M.J.L., de Blainville, H.M.L., Leach, W.E., (eds.), Dictionnaire des sciences naturelles, dans lequel on traite méthodiquement des différents êtres de la nature. Par plusieurs professeurs du Jardin du Roi, et des principales écoles de Paris: Strasbourg and Paris, Levrault, 568 p.

Fatmi, A.N., Kennedy, W.J., 1999, Maastrichtian ammonites from Balochistan, Pakistan: Journal of Paleontology, 73, 641-662.

Forbes, E., 1846, Report on the Cretaceous fossil invertebrates from southern India, collected by Mr. Kaye and Mr. Cunliffe: Transactions of the Geological Society of London (Part 2), 7, 97-174, plates 7-19.

Gill, T., 1871, Arrangement of the Families of Mollusks: Washington, Smithsonian Institution, $49 \mathrm{p}$. 
Goldhammer, R.K., Johnson, C.A., 2001, Middle Jurassic-Upper Cretaceous paleogeographic evolution and sequence-stratigraphic framework of the northwest Gulf of Mexico rim: American Association of Petroleum Geologists Memoir, 75, 45-81.

Goolaerts, S., 2010, Late Cretaceous ammonites from Tunisia: Chronology and causes of their extinction and extrapolation to other areas: Leuven, Belgium, Katholieke Universiteit Leuven, $\mathrm{PhD}$ thesis, $220 \mathrm{p}$.

Henderson, R.A., 1970, Ammonoidea from the Mata Series (Santonian Maastrichtian) of New Zealand: Special Papers in Palaeontology, $6,1-82$.

Henderson, R.A., McNamara, K.J., 1985, Maastrichtian non-heteromorph ammonites from the Miria Formation, Western Australia: Palaeontology, 28, 35-88.

Hoepen, E.C.N. van, 1921, Cretaceous Cephalopoda from Pondoland: Annals of the Transvaal Museum, 8, 1-48.

Hyatt, A., 1889, Genesis of the Arietidae: Smithsonian Contributions to Knowledge, 673, Washington, DC, xi+238 p., 16 plates.

Hyatt, A., 1900, Cephalopoda, in Zittel von, K.A. (ed.), Textbook of Palaeontology: London \& New York, Macmillan, 502-604.

Ifrim, C., Stinnesbeck, W., 2010, Migration pathways of the late Campanian and Maastrichtian shallow facies ammonite Sphenodiscus in North America: Palaeogeography, Palaeoclimatology, Palaeoecology, 292, 96-102.

Ifrim, C., Stinnesbeck, W., Lopez-Oliva, J.G., 2004, Maastrichtian Cephalopods from the Méndez Formation at Cerralvo, Northeastern Mexico: Palaeontology, 47, 1575-1627.

Ifrim, C., Stinnesbeck, W., Schafhauser, A., 2005, Maastrichtian shallowwater ammonites of northeastern Mexico: Revista Mexicana de Ciencias Geológicas, 22, 48-64.

Ifrim, C., Stinnesbeck, W., Rodríguez Garza, R., Ventura, J.F., 2010, Hemipelagic cephalopods from the Maastrichtian (Late Cretaceous) Parras Basin at La Parra, Coahuila, Mexico, and their implications for the correlation of the lower Difunta Group: Journal of South American Earth Sciences, 29, 597-618.

Kennedy, W.J., 1986a, The ammonite fauna of the Calcaire à Baculites (Upper Maastrichtian) of the Cotentin Peninsula (Manche, France): Palaeontology, 29, 25-83.

Kennedy, W.J.,1986b, The ammonite fauna of the type Maastrichtian with a revision of Ammonites colligatus Binkhorst, 1861.: Bulletin de l'Institut Royal des Sciences Naturelles de Belgique, Sciences de la Terre, 56, 151-267.

Kennedy, W.J., Hancock, J.M., 1993, Upper Maastrichtian ammonites from the Marnes de Nay between Gan and Rébénacq (PyrénéesAtlantiques), France: Geobios, 26 (5), 575-594.

Kennedy, W.J., Henderson, R.A., 1992, Non-heteromorph ammonites from the Upper Maastrichtian of Pondicherry, south India: Palaeontology, 35 (2), 381-442.

Kennedy, W.J., Cobban, W.A., 1993a, Ammonites from the Saratoga Chalk (Upper Cretaceous), Arkansas: Journal of Paleontology, 67, 404-434.

Kennedy, W.J., Cobban, W.A., 1993b, Maastrichtian ammonites from the Corsicana Formation in northeast Texas: Geological Magazine, 130, 57-67.

Kennedy, W.J., Cobban, W.A., 2000, Maastrichtian (Late Cretaceous) ammonites from the Owl Creek Formation in northeastern Mississippi, U.S.A: Acta Geologica Polonica, 50, 175-190.

Kennedy, W.J., Klinger, H.C., 1976, Cretaceous faunas from Zululand and Natal, South Africa. The ammonite family Phylloceratidae: Bulletin of the British Museum of Natural History (Geology), 27, 347-380.

Kennedy, W.J., Klinger, H.C., 1977, Cretaceous faunas from Zululand and Natal, South Africa. The ammonite family Tetragonitidae Hyatt, 1900: Annals of the South African Museum, 73, 149-197.

Kennedy, W.J., Klinger, H.C., 1979, Cretaceous faunas from Zululand and Natal, South Africa. The ammonite family Gaudryceratidae: Bulletin of the British Museum of Natural History (Geology), 31, 121-173.

Kennedy, W.J., Gale, A.S., Hansen, T.A., 2001, The last Maastrichtian ammonites from the Brazos River sections in Falls County, Texas: Cretaceous Research, 22, 163-171.

Klinger, H.C., Kennedy, W.J., 2005, Additions to the upper Maastrichtian ammonite faunas from Richards Bay, KwaZulu-Natal, South Africa: African Natural History, 3, 117-121.

Kossmat, F., 1895, Untersuchungen über die Südindische Kreideformation. Erster Theil: Beiträge zur Paläontologie Österreich-Ungarns und des Orient, 9, 97-203 (201-107), plates 15-25.

Kossmat, F., 1897, Untersuchungen über die Südindische Kreideformation. Zweiter Theil: Beiträge zur Paläontologie Österreich-Ungarns und des Orient, 11, 1-46 (108-153), plates 1-8 (12-19).

Lamarck, J.B.P.A.M., 1799, Prodrome d'une nouvelle classification des coquilles: Mémoirs du Musée de l'Histoire Naturelle, 63-90.

Landman, N.H., Waage, K.M., 1993, Scaphitid ammonites of the Upper Cretaceous (Maastrichtian) Fox Hills Formation in South Dakota and Wyoming: Bulletin of the American Museum of Natural History, 215, 1-257.

Landman, N.H., Johnson, R.O., Edwards, L.E., 2004a, Cephalopods from the Cretaceous/Tertiary boundary interval on the Atlantic Coastal Plain, with a description of the highest ammonite zones in North America. Part 2. Northeastern Monmouth County, New Jersey: Bulletin of the American Museum of Natural History, 287, 1-107.

Landman, N.H., Johnson, R.O., Garb, M.P., Edwards, L.E., Kyte, F.T., 2004b, Cephalopods from the Cretaceous/Tertiary boundary interval on the Atlantic Coastal Plain, with a description of the highest ammonite zones in North America. Part 3, Manasquan River Basin, Monmouth County, New Jersey: Bulletin of the American Museum of Natural History, 303, 1-122.

Lawton, T.F., Vega, F.J., Giles, K.A., Rosales-Domínguez, C., 2001, Stratigraphy and origin of the La Popa Basin, Nuevo León and Coahuila, Mexico: American Association of Petroleum Geologists Memoir, 75, 219-240.

Li, L., Keller, G., 1998a, Diversification and extinction in CampanianMaastrichtian planktic foraminifera of Northwestern Tunisia: Eclogae Geologicae Helveticae, 91, 75-102.

Li, L., Keller, G., 1998b, Maastrichtian climate, productivity and faunal turnovers in planktic foraminifera on South Atlantic DSDP sites 525A and 21: Marine Micropaleontology, 33, 55-86.

Machalski, M., Jagt, J.M.W., Landman, N.H., Motchurova-Dekova, N., 2007, The highest records of North American scaphitid ammonites in the European Maastrichtian (Upper Cretaceous) and their stratigraphic implications: Acta Geologica Polonica, 57, 169-185.

Machalski, M., Jagt, J.M.W., Landman, N., Uberna, J., 2009, First record of the North American scaphitid ammonite Discoscaphites iris from the upper Maastrichtian of Libya: Neues Jahrbuch für Geologie und Paläontologie - Abhandlungen, 254, 373-378.

Matsumoto, T., 1959, Upper Cretaceous Ammonites of California, Part II: Memoirs of the Faculty of Science, Kyushu University, Series D, Geology, sp. vol. 1, 1-172, plates 1-41.

Meek, F.B., 1871, A preliminary list of fossils, collected by Dr. Hayden in Colorado, New Mexico and California, with brief descriptions of a few of the new species: Proceedings of the American Philosophical Society, 11, 425-431.

Morton, S.G., 1834, Synopsis of the Organic Remains of the Cretaceous Group of the United States: Philadelphia, Key \& Biddle, 88 p.

Olivero, E.B., Zinsmeister, W.J., 1989, Large Heteromorph ammonites from the Upper Cretaceous of Seymour Island, Antarctica: Journal of Paleontology, 63, 626-636.

Orbigny, A. d', 1850, Prodrome de Paléontologie stratigraphique universelle des animaux mollusques et rayonnées, vol. 2: Paris, Masson, $428 \mathrm{p}$.

Pervinquière, L., 1907, Études de paléontologie tunisienne 1: Céphalopodes des terrains sécondaires, Carte Géologique de Tunisie: Paris, De Rudeval, 438 p., 10 plates.

Salazar, C., Stinnesbeck, W., Quinzio-Sinn, L.A., 2010, Ammonites from the Maastrichtian (Upper Cretaceous) Quiriquina Formation in central Chile: Neues Jahrbuch für Geologie und Paläontologie Abhandlungen, 257, 181-236.

Salfeld, H., 1924, Die Bedeutung der Konservativstämme für der Stammesentwicklung der Ammonoideen, Leipzig, $16 \mathrm{p}$.

Say, T., 1820, Observations on some species of zoophytes, shells, etc, principally fossil: American Journal of Science and Arts, 2, 34-45. 
Schafhauser, A., Götz, S., Stinnesbeck, W., 2007, Rudist decline in the Maastrichtian Cardenas Formation (East-central Mexico): Palaeogeography, Palaeoclimatology, Palaeoecology, 251, 210-221.

Shimizu, S., 1934, Ammonites, in Shimizu, S., Obata, T. (eds.), Cephalopoda. Iwanami's lecture series of Geology and Palaeontology, Tokyo, 1-137, [in Japanese].

Soegaard, K., Daniels, A.T., Ye, H., Arney, J., Halik, N., Garrick, S., 2003, Stratigraphic evolution of Latest Cretaceous to early Tertiary Difunta Foreland Basin in northeast Mexico: Influence of Salt withdrawal on tectonically induced subsidence by the Sierra Madre Oriental fold and thrust best, in Bartolini, C., Buffler, R.T., Blickwede, J.F. (eds.), The Circum-Gulf of Mexico and the Caribbean: Hydrocarbon Habitats, Basin Formation, and Plate Tectonics: Tulsa, Oklahoma, American Association of Petroleum Geologists, AAPG Memoir 79, 364-394.

Spath, L.F., 1926, On new ammonites from the English Chalk: Geological Magazine, 63, 77-83.

Spath, L.F., 1927, Revision of the Jurassic Cephalopod Fauna of Kachh (Cutch), part 1: Memoirs of the Geological Survey of India, Palaeontologica Indica (new series), 9 (2), 1-71.

Stinnesbeck, W., 1986, Zu den faunistischen und palökologischen Verhältnissen in der Quiriquina Formation (Maastrichtium) ZentralChiles: Palaeontographica, 194 (4-6), 99-237.

Stinnesbeck, W., Keller, G., Adatte, T., López-Oliva, J.G., MacLeod, N., 1996, Cretaceous-Tertiary boundary clastic deposits in NE Mexico: Bolide impact or sea-level lowstand?, in MacLeod, N., Keller, G. (eds.), Cretaceous-Tertiary Mass Extinction: Biotic and Environmental Changes: New York, W.W. Norton \& Co, 471-517.
Stinnesbeck, W., Ifrim, C., Salazar, C., 2012, The last Cretaceous ammonites in Latin America: Acta Geologica Polonica, 57, 717-728.

Ward, P.D., Kennedy, W.J., 1993, Maastrichtian ammonites from the Biscay Region: Journal of Paleontology, 67 (5 suppl. II), 1-58.

Weidie, A.E., Wolleben, J.A., McBride, E.F., 1972, Late Cretaceous depositional systems in northeastern Mexico: Transactions of the Gulf Coast Association of Geological Societies, 22, 323-329.

Wiedmann, J., 1966, Stammesgeschichte und System der posttriadischen Ammonoideen: ein Überblick: Neues Jahrbuch für Geologie und Paläontologie, Abhandlungen, 125 (1-3), 49-78, 127, 113-181.

Woods, H., 1906, The Cretaceous fauna of Pondoland: Annals of the South African Museum, 4, 275-350.

Wright, C.W., 1996, Cretaceous Ammonoidea, in Kaesler, R.L. (ed.), Treatise on Invertebrate Paleontology, Part L, Mollusca 4, revised: Lawrence, Kansas and Boulder, Colorado, University of Kansas \& Geological Society of America, $362 \mathrm{p}$.

Yabe, H., Shimizu, S., 1924, A new species of Brahmaites from the Upper Cretaceous of S. Saghalin with some remarks on the genus Brahmaites: Japanese Journal of Geography, 3, 77-80.

Zittel, K.A. von, 1884, Cephalopoda, Handbuch der Paläontologie, 1, Abteilung 2, Lieferung 3: München, Leipzig, R. Oldenburg, 329-522.

Zittel, K.A. von, 1895, Grundzüge der Paläontologie, München, Germany, R. Oldenburg, viii+971 p.

Manuscript received: September 23, 2012.

Corrected manuscript received: December 10, 2012.

Manuscript accepted: December 13, 2012. 